\title{
Az oxidatív stressz szerepe a diabeteses neuropathia kialakulásában
}

\author{
Sztanek Ferenc dr. - Molnárné Molnár Ágnes - Balogh Zoltán dr. \\ Debreceni Egyetem, Általános Orvostudományi Kar, Klinikai Központ, Belgyógyászati Intézet, \\ Anyagcsere-betegségek Tanszék, Debrecen
}

\begin{abstract}
A diabeteses neuropathia egyik leggyakoribb és súlyos szövődmény lehet diabetes mellitusban. Az oxidatív stressz fontos szerepet játszik a cukorbetegség microvascularis komplikációinak progressziójában. A fokozott oxidatív stressz elősegíti bizonyos kóros metabolikus útvonalak, mint a poliol- és hexózamin-útvonal, az előrehaladott glikációs végtermékek, a poli-ADP-ribóz polimeráz és a proteinkináz-C aktivációját. Jelen összefoglalóban a szerzók áttekintik az oxidatív stressz és a cukorbetegség kapcsolatának legfrissebb ismereteit és összegzik a fokozott oxidatív stressz patofiziológiai hatásait a diabeteses neuropathia kialakulásában. A diabeteses neuropathia kezelésében alkalmazott modern gyógyszerek vizsgálatában még intenzív, hosszú távú összehasonlító vizsgálatokra van szükség a közeljövőben. Orv. Hetil., 2016, 157(49), 1939-1946.
\end{abstract}

Kulcsszavak: diabeteses neuropathia, oxidatív stressz, gyulladás, endothelialis diszfunkció, microvascularis szövődmények

\section{The role of oxidative stress in the development of diabetic neuropathy}

Diabetic neuropathy may be one of the most common and severe complications of diabetes mellitus. Oxidative stress plays a pivotal role in the development of microvascular complications of diabetes. The majority of related pathways like polyol and hexosamine, advanced glycation end products, poly-ADP-ribose polymerase, and protein kinase-C all originated from initial oxidative stress. In this review, the authors present the current oxidative stress hypothesis in diabetes mellitus and summarize the pathophysiological mechanisms of diabetic neuropathy associated with increased oxidative stress. The development of modern medicines to treat diabetic neuropathy needs intensive long-term comparative trials in the future.

Keywords: diabetic neuropathy, oxidative stress, inflammation, endothelial dysfunction, microvascular complications

Sztanek, F., M. Molnár, Á., Balogh, Z. [The role of oxidative stress in the development of diabetic neuropathy]. Orv. Hetil., 2016, 157(49), 1939-1946.

(Beérkezett: 2016. szeptember 11.; elfogadva: 2016. október 13.)

\section{Rövidítések}

ADMA = aszimmetrikus dimetil-arginin; AGE-k = elörehaladott glikációs végtermékek; DN = diabeteses neuropathia; GAPDH = glicerinaldehid-3-foszfát-dehidrogenáz; IL-1b/-6 $=$ interleukin- $\mathrm{lb} /-6 ; \mathrm{MDA}=$ malondialdehid $\mathrm{NF} \kappa \mathrm{B}=$ nuclear factor kappa-light-chain-enhancer of activated $\mathrm{B}$ cells; NGF = idegi növekedési faktor; $\mathrm{NO}=$ nitrogén-monoxid; PAI-1 = 1-es típusú plazminogénaktivátor-inhibitor; PARP = poli(ADPribóz)-polimeráz; $\mathrm{PKC}=$ proteinkináz-C; $\mathrm{RAGE}=$ előrehaladott glikációs végtermékek receptora; ROS = reaktív oxigén- gyökök; T2DM = 2-es típusú cukorbetegség; TBARS = tiobarbitursav-reaktív anyagok; TGF- $\beta=$ transzformáló növekedési faktor-béta; TNF- $\alpha=$ tumornekrózis-faktor-alfa; VEGF $=$ vascularis endothelialis növekedési faktor

A polyneuropathiák gyưjtőfogalma alatt a perifériás és autonóm idegek degeneratív károsodását értjük, amely legtöbbször valamilyen anyagcsere-betegség vagy toxikus ártalom következtében alakul ki, leggyakoribb endo- 
gén ok a cukorbetegség [1]. A perifériás diabeteses neuropathia (DN) leggyakrabban az alsó végtagok distalis idegrostjait érinti, szimmetrikus szenzomotoros formában észlelhető, rendszerint évekkel a cukorbetegség felfedezését követően diagnosztizálják, és progressziója az anyagcserehelyzettel szoros kapcsolatban áll. Meghatározó szerepet játszik a diabeteses láb kialakulásában, amelyben számos patológiai eltérés (szomatikus és az autonóm neuropathia, diabeteses micro- és macroangiopathia, csont- és ízületi elváltozások, talpi fekélyek, infekció) együttes hatása figyelhető meg. A diabeteses láb szövődményei sokszor a végtag maradandó funkcionális károsodásával és végső soron amputációval járnak $[1,2]$. A diabetes microvascularis szövődményeként vegetatív idegrendszeri károsodás, szív- és érrendszeri betegségek alakulhatnak k. Az autonóm idegrendszeri károsodás és a myocardialis ischaemia közötti kapcsolat igazolható autonóm idegrendszeri tesztek segítségével $[3,4]$. Szoros összefüggést találtak az autonóm neuropathia, a következményes relatív szimpatikus aktivitás túlsúlya és az essentialis hypertonia kialakulása között, valamint az autonóm neuropathia és az inzulinrezisztencia súlyossága között is, ezek hátterében a kóros anyagcsere-útvonalak aktiválódása és a fokozott oxidatív stressz kiemelt fontosságúnak tünik $[5,6]$.

\section{Oxidatív stressz diabeteses neuropathiában}

2-es típusú diabetes mellitusban (T2DM) az oxidatív stressz fontos szerepet játszik a hyperglykaemia indukálta sejtkárosodás és a microvascularis komplikációk (diabe- teses retinopathia, nephropathia és neuropathia, generalizált atherosclerosis) kialakulásában. Az oxidatív stressz fokozódása a prooxidáns és az antioxidáns tényezők közötti egyensúly megbomlását jelenti a szervezetben. A hyperglykaemia különböző kóros anyagcsere-útvonalak aktiválásával fokozza a prooxidánsok terelődését, amelyek celluláris károsodások és gyulladásos folyamatok révén vesznek részt a DN kialakulásában (1. ábra) [7]. A magas intracelluláris vércukorszint elősegíti a szabad oxigéngyökök képződését, a mitokondriális elektrontranszport múködése során a szuperoxid-termelődés fokozódik [8]. A képződő reaktív oxigéngyökök (ROS) elősegítik az előrehaladott glikációs végtermékek (AGEs) képződését, amely a lipidek, nukleinsavak és fehérjék nem enzimatikus glikációja révén keletkező heterogén vegyületcsoport. A cytoskeletalis fehérjék glikációja az idegrostok strukturális és funkcionális károsodását okozza, továbbá az idegeket ellátó kapillárisok bazális membránjának a megvastagodása, a pericyták degenerációja és endothelsejtek hyperplasiája is igazolódott [9]. Az oxidatív stressz hatására az idegrostok vérellátásának károsodása mellett kóros metabolikus változások figyelhetők meg. Az aldózreduktáz-aktivitás és a nem enzimatikus glikáció fokozódik, a szuperoxidgyökök mitokondriális termelődésével párhuzamosan a poliol- és hexózaminútvonalak, az AGE-k fokozott képződése és a proteinkináz-C- (PKC-) útvonal aktivációja igazolható a perifériás idegekben [10]. Megváltozott génexpresszió, gyulladásos citokinek fokozott termelődése és apoptózisindukció is szerepet játszik a DN kialakulásában [11]. Az antioxidánsok gátolják a szuperoxidgyökök akkumulációját a

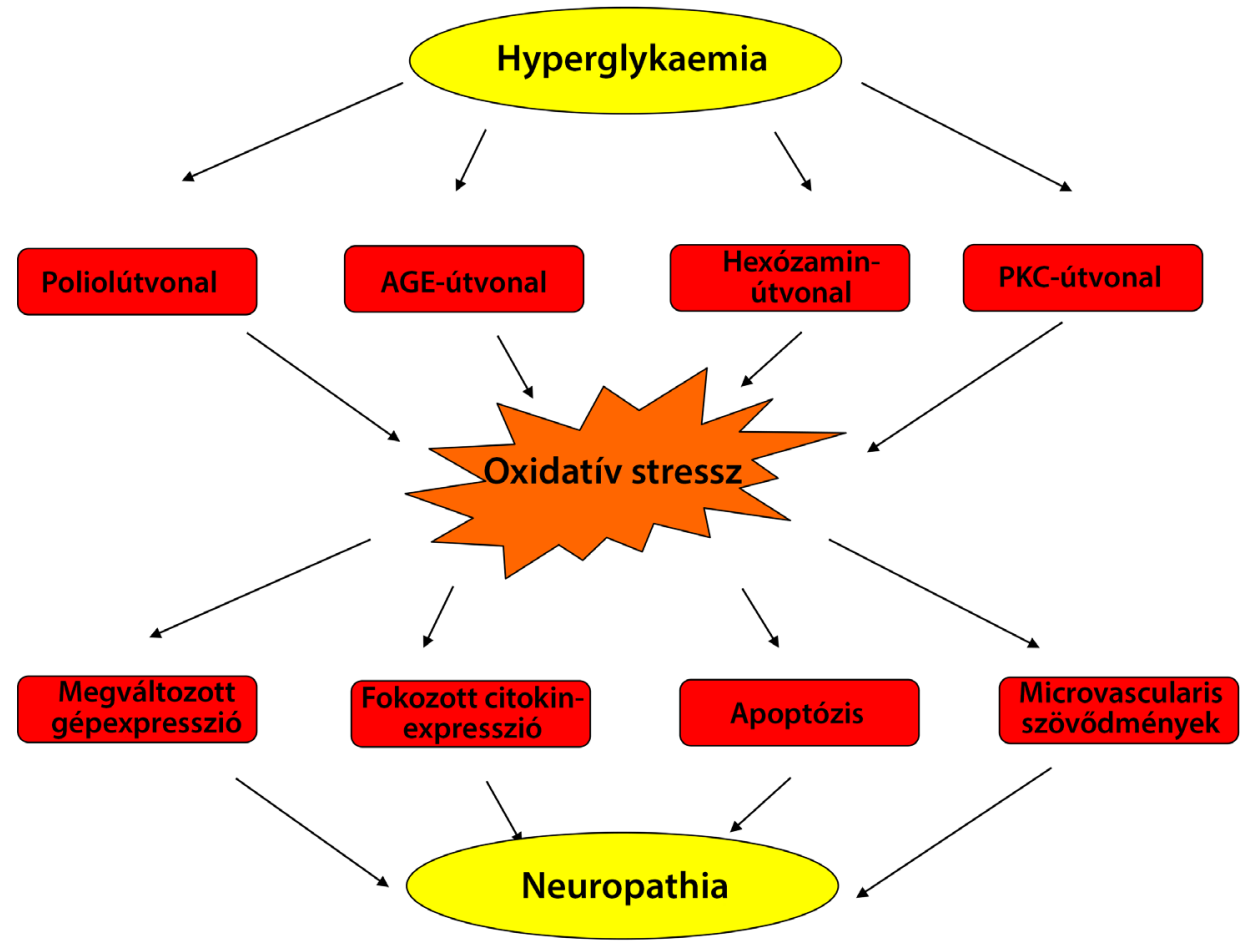


perifériás idegekben, a vércukorszint normalizálásával együtt a szövődmények progressziója is lassítható [8]. Különböző antioxidáns tulajdonságú enzimek és endogén vegyületek termelődése vagy külső forrásokból való bevitele csökkentheti a prooxidáns folyamatokat. Ilyenek például a flavonoidok, a bilirubin, a húgysav, az albumin, C- és E-vitaminok, az $\alpha$-liponsav, glutation, szuperoxiddizmutáz és kataláz enzimek. Ezen antioxidáns kapacitás kimerülése esetén számolhatunk jelentős oxidatív stressz jelenlétével.

\section{A reaktív oxigéngyökök szerepe a diabeteses neuropathiában}

A reaktív oxigéngyökök (ROS) fiziológiásan is termelődnek a szervezetben, ezek közül a legjelentősebbek a szuperoxidion, a hidrogén-peroxid és a peroxinitrit, amelynek a felgyorsult képződése esszenciálisnak tünik a DN kialakulásában. A szuperoxidion és a hidrogén-peroxid strukturálisan-funkcionálisan károsítják a fehérjéket, valamint a nukleáris és a mitokondriális DNS-t, gátolják a mitokondriális enzimek múködését és az ATP-termelést [7]. A nitrogén-monoxid- (NO-) termelődés normális metabolikus környezetben fontos szerepet játszik a mitokondriális elektrontranszport szabályozásában, a molekuláris oxigénnel kompetitíven és reverzibilisen kötődve a citokróm C-oxidázhoz az ATP-termelődés limitáló tényezője. A ROS hatására a NO metabolizmusa megváltozik és a termelődő peroxinitrit irreverzibilisen gátolja az elektrontranszfert és az ATP-szintézist [12]. A peroxinitrit közvetlenül a membrán lipidperoxidációját okozza malondialdehid képződése révén. A ROS indukálta mitokondriális károsodás révén csökken bizonyos neurotróf anyagok, mint az idegi növekedési faktor (NGF) és a neurotrophin-3 termelődése [13].

\section{A poliolútvonal aktiválódása}

Tartós hyperglykaemia és magas intracelluláris glükózszint esetén az idegsejtekben a normális glikolízis telítődik, a poliolútvonal aktiválódásával az aldózreduktáz révén szorbitol, majd a szorbitol-dehidrogenáz által fruktóz keletkezik. A sejtmembrán impermeabilis a szorbitol számára, amelynek akkumulációjával az intracelluláris ozmolaritás tovább nő és kompenzatorikusan egyéb ozmolitok, mint például mio-inozitol, taurin és adenozin áramolnak ki a sejtekből. Ennek következtében az ATP-termelés és a $\mathrm{Na}^{+} / \mathrm{K}^{+}$-ATP-áz múködése is csökken, károsodik az axonális transzport és neuronok strukturális fehérjéi, végül abnormális akciós potenciálok jelentkeznek [14]. Az aldózreduktáz által katalizált glükóz-szorbitol átalakulás NADPH-igényes, amelyhez redukált glutationra van szükség. A glutation regenerációs kapacitás kimerülésével párhuzamosan a szorbitolból fruktóz képződik, ezáltal fokozódik az AGE-k termelődése is. Habár DN-ben a fokozott oxidatív stresszel ösz- szefüggő sejtkárosodásban ezen alternatív anyagcsereútvonal aktiválódása központi fontosságúnak túnik, a diabeteses neuropathia kialakulásában és progressziójában játszott szerepe még nem teljesen tisztázott, a poliolútvonal gátlása aldóz-reduktáz inhibitorokkal (például epalrestat, alrestatin, zopolrestat stb.) mind experimentális, mind klinikai vizsgálatokban ellentmondásos eredményekkel zárult mind a hatékonyság, mind a hatásosság, mind a kedvezőtlen mellékhatásprofil szempontjából [15].

\section{A glikációs végtermékek (advanced glycation end-products - AGE-k) szerepe}

Hyperglykaemiában az oxidatív folyamatok során az AGEs képződése intracellulárisan és extracellulárisan is fokozódik. A három fö prekurzor a glioxál, a metilglioxál és a 3-deoxiglukazon, amelyek a reaktívszénhidrát-csoportjaikkal kapcsolódnak a fehérjékhez, a nukleinsavhoz és a lipidekhez, azok biológiai funkcióit károsítva változtatják meg a sejtmetabolizmust. Extracellulárisan sejtfelszíni receptorhoz (RAGE) kötődnek, különböző szignálútvonalakon (Rho-, Jak/Stat-, Ras- és PKC-útvonal) a sejtmotilitás változását, proinflammatorikus citokinek termelését és apoptózist, az NFkB és a NADPH-oxidáz aktiválásával az oxidatív stressz elmélyülését okozzák, ezáltal az endoneuronalis véráramlás, az idegszöveti integritás és repair mechanizmusok károsodása jön létre DNben $[6,16]$. Az AGE-k képződése az endoneuronalis NO-metabolizmust is károsítja, a következményes vasoconstrictiv hatás és a sejtadhéziós molekulák aktiválódása, valamint a koagulációs aktivitás fokozódásával az idegrostok vérellátása tovább romlik.

\section{A proteinkináz-C- (PKC-) aktiváció}

A PKC jelátviteli útvonal kiemelt szerepet játszik az idegsejtek múködésében és a DN kialakulásában. A PKC enzimcsalád különböző transzkripciós faktorok, metabolikus enzimek és cytoskeletalis fehérjék múködését befolyásolja az azokat alkotó szerin és treonin aminosavak hidroxilcsoportjainak foszforilációja révén, így a szignál transzdukciós útvonalak módosításával befolyásolja a redoxistátuszt [17]. A magas vércukorszint a diacil-glicerol termelődését stimulálja és a PKC intracelluláris szignálkaszkád a PAI-1, VEGF és TGF- $\beta$ termelődését fokozza, valamint a $\mathrm{Na} / \mathrm{K}$-ATP-áz gátlásával az idegsejtek permeabilitása károsodik, fokozódik a vascularis endothelialis sejtek proliferációja $[6,16]$. A PKC aktivációja gátolja az endothelialis NO-szintáz mRNS-ének expresszióját, ezáltal a NO-produkciót is, fokozódik a szuperoxid termelődése, az endothelin-1 aktivitása, így vasoconstrictio és ischaemiás károsodás alakul ki [18]. A PKC közvetítésével aktiválódik egyebek között az NF- $\kappa \mathrm{B}$ transzkripciós faktor is, amely bejutva a sejtmagba, a DNS-hez kötődve számos gén expresszióját szabályozza, amelyek kulcssze- 
repet játszanak a gyulladásos folyamatok, az immunválasz, az apoptózis és a sejtosztódás regulációjában. A PKC-gátlók (például ruboxistaurin) állatkísérletekben gátolták az NF- $\kappa$ B-aktivációt és a következményes ROStermelődést, viszont klinikai vizsgálatok során nem értek el érdemi javulást DN-betegeknél [19, 20].

\section{A hexózamin-útvonal aktiválódása}

A hexózamin alternatív glükózlebontási útvonalon a glikolízis során keletkező fruktóz-6-foszfát átalakul glükózamin-6-foszfáttá, majd konvertálódik uridin-difoszfát-N-acetil-glükózaminná, ami reaktív metabolitként transzkripciós faktorok szerin- és treoninoldalláncaihoz kapcsolódik. A hexózamin-útvonal útján végső soron az Spl transzkripciós faktor aktivitása fokozódik, amely fokozza a TGF- $\beta$ és a PAI-1 termelését, citokinek felszabadulását, gyulladásos választ és apoptózist indukál [21]. A hexózamin-útvonal aktiválódása az endothelialis NOszintázt gátolja, valamint az inzulinrezisztenciát is fokozza [22].

\section{A NO-deficientia/ endotheldiszfunkció szerepe}

$\mathrm{Az}$ idegsejtek vérellátásának romlása, a hypoxia és az idegsejteken belüli energiatermelő biokémiai folyamatok károsodása a DN kialakulását elősegíti. Az idegsejtek vérellátásának csökkenése hátterében, úgy tünik, a NO termelődésének zavara kiemelt fontosságú tényező [23]. DN-ben a fokozottan termelődő szuperoxid-anion a mitokondriális elektrontranszport-lánc segítségével kötődik a NO-hoz, és a létrejövő erôsen oxidatív tulajdonságú peroxinitrit károsítja az endothelsejtek értónust és kapilláris permeabilitást szabályzó funkcióit. A NO vasodilatator és antithromboticus hatása kiesik, nem tudja kifejteni antagonizáló hatását az erôsen vasoconstrictiv hatású endothelin-1-gyel szemben [24]. Ezenkívül a NO kompetitíven gátolja a mitokondriális citokróm oxidáz múködését, így csökkenti a szuperoxid-termelődést, valamint antioxidánsként a lipidperoxidációt is gátolja [12].

\section{A gyulladás szerepe}

Az utóbbi években többen vizsgálták a krónikus gyulladásos folyamatok összefüggéseit az elhízással és az inzulinrezisztenciával [14, 25]. Magasabb IL-1b-, IL-6- és TNF- $\alpha$-szintek mérhetők T2DM-betegeknél, és összefüggés mutatható ki e gyulladásos markerek és a DN incidenciája között $[14,26]$. A hyperglykaemia indukálta alternatív anyagcsere-útvonalakon több proinflammatorikus anyag (például NF- $\kappa \mathrm{B}, \mathrm{TGF}-\beta, \mathrm{TNF}-\alpha$ stb.) keletkezik. Az NF- $\kappa$ B aktiválja a COX-2-t, ezáltal fokozza a prosztaglandin-E2 és a ROS képződését, amely utóbbi triggerként szolgál az NF- $\kappa \mathrm{B}$ további képződéséhez. Feltételezhetően DN-ben a krónikus NF- $\kappa \mathrm{B}$-aktiváció központi szerepet játszik a krónikus gyulladásos folyamatok fenntartásában [27]. A hyperglykaemia és hypoxia okozta macrophagaktiváció, a termelődő citokinek általi NF- $\kappa$ B-indukció a Schwann-sejtekben, az endotheliumban és a neuronokban fokozza a ROS képződését, ezáltal az idegsejtek és a myelinhüvely oxidatív károsodását okozza DN-ben. Az NF- $\kappa$ B specifikus inhibitorokkal való gátlásával experimentális vizsgálatokban javult a motoros és szenzoros idegi vezetési sebesség, az autonóm és endothelialis diszfunkció [28, 29], azonban a klinikai alkalmazásuk egyelőre még kérdéses. Az utóbbi években többen vizsgálták a DN-ben alkalmazott -liponsav-terápia antioxidáns hatását, az eredmények alapján a tartós kezelés növeli a redukáltglutation-szintet, kedvezően módosítja az inzulin és az NF- $\kappa \mathrm{B}$-szignál transzdukciós útvonalakat [30], javítja az endotheldiszfunkciót és egyes vizsgálatok alapján a gyulladásos folyamatokra hatva az érelmeszesedés progresszióját is lassíthatja [31].

\section{Celluláris és mitokondriális oxidatív stressz}

A mitokondrium a terminális oxidáció mellett a ROStermelődés központja is, ahol kis mennyiségben normálkörülmények között is termelődik szuperoxid-anion. Hyperglykaemiában az elektrondonorok, mint a NADH és a FADH2, fokozott termelődése figyelhető meg, ezáltal megnövekszik a szabad gyökök termelése a terminális oxidáció során, amit elősegít a NADH-oxidáz kórosan megváltozott aktivitása és a PKC aktivációja is [32]. A poliol- és hexózamin-útvonalak, valamint a PKC aktivációja gátolja a glikolízis második fázisának kulcsenzimének, a NAD+-igényes glicerinaldehid-3-foszfát-dehidrogenáznak (GAPDH) a múködését, amelynek hátterében a ROS által kiváltott DNS-károsodás és következményes poli(ADP-ribóz)-polimeráz- (PARP-) aktiváció állhat. A PARP kötődik a sérült DNS-szakaszhoz és ADP-ribóz polimereket képez, ezáltal részt vesz a repair folyamatában. Azonban a PARP enzimatikusan a $\mathrm{NAD}^{+}$bomlását katalizálja, nikotinsav és ADP-ribóz termelődik, így a $\mathrm{NAD}^{+}$depléciója mellett az ADP-ribóz polimerek akkumulációja figyelhető meg a GAPDH enzimen [33]. Ennek következtében lassul a glikolízis folyamata és alternatív útvonalak aktiválódnak, így a PARPaktiváció is kapcsolatban van a diabeteses szövődmények kialakulásával. Kedvező experimentális kísérleti eredmények után több szerző felvetette a PARP-gátlók lehetséges kedvező terápiás hatását DN-ben [34]. Ezenkívül az oxidatív stressz csökkentésében és az alternatív anyagcsereutak gátlásában az antioxidáns tulajdonságú $\alpha$-liponsav neuroprotektív szerepét találták. Javul a neuronalis vezetési sebesség $\alpha$-liponsav és a szintén antioxidáns tulajdonságú ubikinon terápiás alkalmazásával [35]. 


\section{Az oxidatív stresszt jellemző biomarkerek diabeteses neuropathiában}

Az oxidatív stressz fokozódásával termelődő reaktív gyökök lipidperoxidációt okoznak a sejtmembránban, lipidhidroperoxidok és nagy reaktivitású metastabil aldehidek, többek között a malondialdehid képződik, amelyek bomlásuk során a lipidektől további hidrogént vonnak el, így fokozzák a sejtmembrán károsodását. A malondialdehid (MDA) alkalmas biomarkernek tünik a szabad gyökök által kiváltott lipidkárosodás és az oxidatív stressz jellemzésére diabeteses betegekben [36]. A fokozott lipidperoxidáció az enzimatikus és nem enzimatikus antioxidáns védelem csökkenésére is utalhat, és összefüggés mutatható ki az emelkedett MDA-koncentráció és a microvascularis szövődmények között T2DM-ben. Az MDA és a lipid-hidroperoxidok mérésére alkalmas assaykitek kereskedelmi forgalomban elérhetők, valamint a lipidperoxidáció meghatározására leggyakrabban használt teszt, a tiobarbitursav-reaktív anyagok (TBARS) vizsgálata is alkalmas lehet. A tiobarbitursav az MDA-val reagál, mérhető fluoreszcens termék képződik és a lipidperoxidáció mértéke a plazma teljes lipidfrakciójából a lipid-hidroperoxid és a TBARS mennyiségének mérésével határozható meg [37].

A ROS-képződés a különböző proteinek és enzimek strukturális és funkcionális károsodását okozza aminosav-oldalláncok (cisztein, tirozin és metionin) módosításával. A hyperglykaemiában az AGE-k képződésével öszszefüggően reaktív dikarbonilok keletkeznek, és az úgynevezett karbonilstressz a mitokondriális fehérjék károsításával elősegíti a diabeteses szövődmények progresszióját. Az utóbbi években igazolódott a diabeteses nephropathia mellett a diabeteses neuropathia kialakulásában is az AGE-képződés és a karbonilstressz szerepe [38]. A proteinkarbonil-csoportok meghatározása (például ELISA-módszerrel) az oxidatív stressz mértékét jellemző, hasznosítható módszernek tûnik.

A NO vasodilatator hatása jól ismert, emellett számos anyagcsere- és proliferációs folyamatban játszik közvetlen vagy szabályozó szerepet, a NO képződésének csökkenése a micro- és macrovascularis szövődmények kialakulásában is fontos tényező. A cukorbetegségben észlelhető felgyorsult érelmeszesedés összefüggést mutat az endothel diszfunkciójával és a NO endothel által történő termelődési mechanizmusának károsodásával is. Ezzel a folyamattal összefüggő biokémiai változások megfelelő markerként szolgálhatnak a cardiovascularis morbiditás jellemzésére. A szervezet által endogén úton termelt és kórosan felhalmozódó aszimmetrikus dimetilarginin (ADMA) endogén inhibitora a NO-szintáz enzimnek, ezáltal befolyásolja az endothelialis diszfunkciót és az érelmeszesedést [39]. Pozitív korrelációt mutattak ki az emelkedett ADMA-szint és a koszorúér-eredetű betegségek között, és friss irodalmi adatok összefüggést mutattak ki a NO metabolizmusának változása és a diabeteses polyneuropthia progressziója között [40].
A glutation antioxidáns szerepe régóta ismert, tiolcsoportja révén reverzibilisen oxidálódhat és így segíti a fehérjék kéntartalmú oldalláncainak redukált állapotban tartását, elősegíti a reaktív gyökök eliminálását, koenzimként szolgál számos enzimreakcióban, ezért a sejtszintû redoxiegyensúly felborulásával kapcsolatos biomarkerként szolgálhat [25]. A glutation-peroxidáz enzim a glutation oxidálásával neutralizálja a hidrogénperoxidot, az oxidált glutation redukcióját a glutationreduktáz végzi. Csökkent glutation- és glutation-peroxidáz-szint mutatható ki 2-es típusú cukorbetegségben, és jelzője lehet az oxidatív DNS-károsodásnak is [41]. A kataláz enzim a hidrogén-peroxid bomlását katalizálja, így fejti ki antioxidáns tulajdonságát a lipid- és proteinperoxidációval, DNS- és RNS-károsodással szemben. A hyperglykaemia fokozza a szuperoxid és a hidrogénperoxid termelődését, a deficiens katalázaktivitással a $\beta$-sejt-diszfunkciót okozó mitokondriális szintû ROS-károsodás szoros kapcsolata mutatható ki 2-es típusú cukorbetegségben [42]. A szuperoxid-dizmutáz enzim a szuperoxid-anion hidrogén-peroxidra és molekuláris oxigénre való átalakulását segíti elő, így csökkenti a ROS által kiváltott celluláris károsodást. Fontos szerepet játszik a diabeteses nephropathia és retinopathia kialakulásában az apoptózis regulációja révén [43, 44], és experimentális kutatások alapján a diabeteses neuropathia kialakulásában is szerepe lehet [45].

A vizeletből izolálható nukleinsav- és prosztaglandinanyagcsere közti termékei is utalhatnak a fokozott oxidatív stresszel összefüggő gyulladás és DNS-károsodás mértékére diabeteses betegekben. A vizeletmintában kimutathatók a peroxinitrit-anion által oxidált fehérjék aminosav-származékok (például 3-nitrotirozin), a lipidperoxidációt jellemző 8-epi-prosztaglandin és a DNSkárosodás mértékére utaló 8-hidroxi-deoxiguanozin az oxidatív stressz megítélésére jól használható biomarkereknek bizonyultak l-es és 2-es típusú cukorbetegségben egyaránt [46].

\section{Terápiás lehetőségek az oxidatív folyamatok mérséklésére}

A DN kezelésének elengedhetetlen feltétele a szénhidrát-anyagcsere tartós rendezése. Az l-es típusú cukorbetegségben a Diabetes Control and Complications Trial (DCCT), a 2-es típusú cukorbetegségben a UKPDS igazolta a szoros anyagcsere-vezetés kedvezőbb, a microvascularis szövődmények kockázatát csökkentő hatását a kevésbé szoros anyagcserekontrollhoz képest. A tartósan rendezett, közel normoglykaemiás állapot mellett kiemelt jelentősége van az antioxidáns természetư, membránstabilizáló $\alpha$-liponsav és a szintén antioxidáns, transzketoláz-aktivátor benfotiamin alkalmazásának. A SYDNEY vizsgálatban a parenteralisan adott $\alpha$-liponsav-terápia mellett jelentős javulást észleltek a DN-betegeknél, és ezt részben az $\alpha$-liponsav antioxidáns, reaktív szabad gyököket megkötő tulajdonságával hozták összefüggés- 


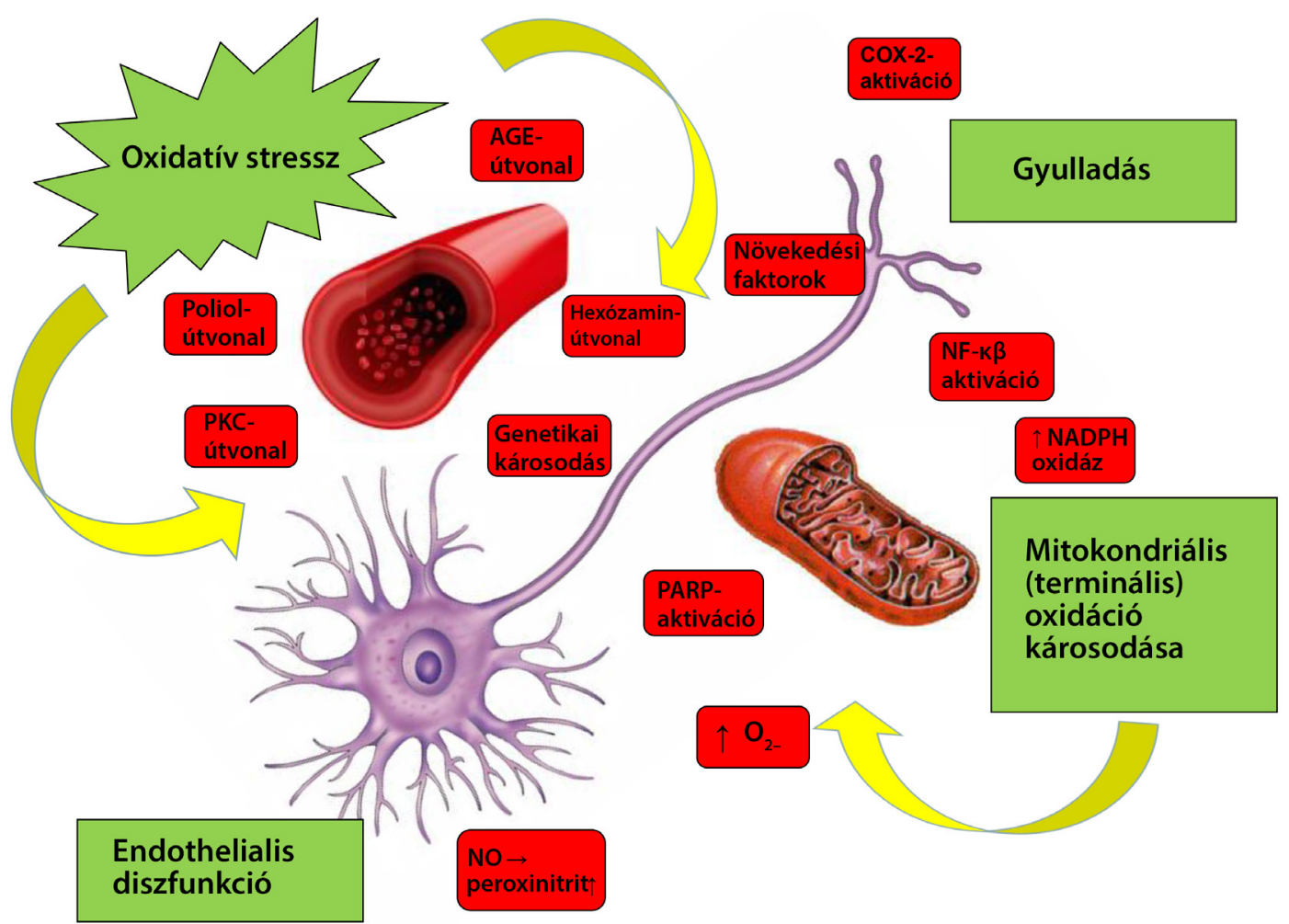

2. ábra $\quad$ Az oxidatív stressz fokozódása, krónikus gyulladásos folyamatok és az endothelialis diszfunkció a terminális oxidáció károsodásával és az ATP-képződés zavarával okozza a diabeteses neuropathia progresszióját

be [47]. A NATHAN 1 tanulmányban az $\alpha$-liponsavterápiával elért klinikai javulás mellett a DN progressziójának mérséklődését találták [48]. A benfotiamin igazolt módon gátolja a PKC-anyagcsereutat, továbbá aldózreduktáz-gátló tulajdonsággal rendelkezik, emellett gátolja in vitro vesesejtekben az oxidatív DNS-károsodást, antioxidánsként a reaktív oxidatív gyökök sejthatásait csökkenti [49]. A jövő ígéretes terápiás lehetőségei lehetnek, de egyelőre a klinikai eredmények elmaradnak a PKCgátlók, aldózreduktáz-inhibitorok, az NGF-gátlók és a VEGF-antagonisták alkalmazásával DN-ben.

\section{Következtetések}

A cukorbetegség szövődményeként kialakuló vascularis károsodások (atherosclerosis, retino-, nephro- és neuropathia) és az oxidatív stressz között szoros összefüggés mutatható ki. Az oxidatív stressz kialakulásában egyrészt prooxidáns tényezők, reaktív oxigéngyökök jelenléte, másrészt a védőhatású antioxidáns tulajdonságú faktorok (antioxidáns vitaminok és enzimatikus védelem) csökkent szintje játszik szerepet. A DN kialakulásában a magas vércukorszint okozta ozmotikusan károsító hatás, a glikolízis felgyorsulása, a glikációs végtermékek felszaporodása, az endoneuronalis vérellátás károsodása és az endotheldiszfunkció, a nitrogén-monoxid- (NO-) szintézis zavara, különböző alternatív anyagcsereutak (poliol- és hexózamin-anyagcsereútvonal) aktiválódása mellett az oxidatív stressz is fontos szerepet játszik. Végső soron ezek a mechanizmusok okozzák a terminális oxidáció károsodását és az ATP-képződés csökkenését, ezáltal az idegi vezetőképesség romlását (2. ábra) [50]. A kóros folyamatok eredményeként a hyperglykaemiával összefüggôen csökken az antioxidáns védelem, fokozódik a szuperoxid-anion és a szabad gyökök képződése, ezáltal az oxidatív stressz is fokozódik. Csökken az antioxidáns tényezók szintje autonóm DN-ben, ami az endoneuronalis véráramlás károsodásához, következményes hypoxiához és további idegi károsodáshoz vezethet.

Anyagi érdekeltség: A közlemény megírása anyagi támogatásban nem részesült.

Szerzői munkamegosztás: A szerzők a munkában egyenlő arányban vettek részt. A cikk végleges változatát valamennyien elolvasták és jóváhagyták.

Érdekeltségek: A szerzőknek nincsenek érdekeltségeik.

\section{Irodalom}

[1] Kempler, P.: Clinical presentation and diagnosis of diabetic neuropathy. [A diabeteses neuropathia klinikai képe és diagnosztikája.] Orv. Hetil., 2002, 143(20), 1113-1120. [Hungarian]

[2] Boulton, A. J., Vinik, A. I., Arezzo, J. C., et al.: Diabetic neuropathies: a statement by the American Diabetes Association. Diabetes Care, 2005, 28(4), 956-962.

[3] Kempler, P., Tesfaye, S., Chaturvedi, N., et al.: Autonomic neuropathy is associated with increased cardiovascular risk factors: 
the EURODIAB IDDM Complications Study. Diabet. Med., 2002, 19(11), 900-909.

[4] Vinik, A. I., Maser, R. E., Ziegler, D.: Neuropathy: the crystal ball for cardiovascular disease? Diabetes Care, 2010, 33(7), 16881690.

[5] Abbott, C. A., Malik, R. A., van Ross, E. R., et al.: Prevalence and characteristics of painful diabetic neuropathy in a large community-based diabetic population in the UK. Diabetes Care, 2011, 34(10), 2220-2224.

[6] Callaghan, B. C., Cheng, H. T., Stables, C. L., et al.: Diabetic neuropathy: clinical manifestations and current treatments. Lancet Neurol., 2012, 11(6), 521-534.

[7] Hosseini, A., Abdollahi, M.: Diabetic neuropathy and oxidative stress: therapeutic perspectives. Oxid. Med. Cell. Longev., 2013, 2013, ID 168039 .

[8] Brownlee, M.: Biochemistry and molecular cell biology of diabetic complications. Nature, 2001, 414(6865), 813-820.

[9] Cameron, N. E., Eaton, S. E., Cotter, M. A., et al.: Vascular factors and metabolic interactions in the pathogenesis of diabetic neuropathy. Diabetologia, 2001, 44(11), 1973-1988.

[10] Schmeichel, A. M., Schmelzer, J. D., Low, P. A.: Oxidative injury and apoptosis of dorsal root ganglion neurons in chronic experimental diabetic neuropathy. Diabetes, 2003, 52(1), 165-171.

[11] Kostyuk, E. P.: Cellular mechanisms underlying the development of diabetic neuropathies. Neurophysiology, 1998, 30(2), 120127.

[12] Ghafourifar, P., Bringold, U., Klein, S. D., et al.: Mitochondrial nitric oxide synthase, oxidative stress and apoptosis. Biol. Signals Recept., 2001, 10(1), 57-65.

[13] Tomlinson, D. R., Fernyhough, P., Diemel, L. T.: Role of neurotrophins in diabetic neuropathy and treatment with nerve growth factors. Diabetes, 1997, 46(Suppl. 2), S43-S49.

[14] Edwards, J. L., Vincent, A. M., Cheng, H. T., et al.: Diabetic neuropathy: mechanisms to management. Pharmacol. Ther., 2008, $120(1), 1-34$

[15] Schemmel, K. E., Padiyara, R. S., D'Souza, J. J.: Aldose reductase inhibitors in the treatment of diabetic peripheral neuropathy: a review. J. Diabetes Complications, 2010, 24(5), 354-360.

[16] Yan, S. F., Ramasamy, R., Schmidt, A. M.: Mechanisms of disease: advanced glycation end-products and their receptor in inflammation and diabetes complications. Nat. Clin. Pract. Endocrinol. Metab., 2008, 4(5), 285-293.

[17] Williams, B., Gallacher, B., Patel, H., et al.: Glucose-induced protein kinase $\mathrm{C}$ activation regulates vascular permeability factor mRNA expression and peptide production by human vascular smooth muscle cells in vitro. Diabetes, 1997, 46(9), 1497-1503.

[18] Ramzy, D., Rao, V., Tumiati, L. C., et al.: Elevated endothelin-1 levels impair nitric oxide homeostasis through a PKC-dependent pathway. Circulation, 2006, 114(1 Suppl.), I-319-I-326.

[19] Vinik, A. I., Bril, V., Kempler, P., et al.: Treatment of symptomatic diabetic peripheral neuropathy with the protein kinase $\mathrm{C}$ $\beta$-inhibitor ruboxistaurin mesylate during a 1-year, randomized, placebo-controlled, double-blind clinical trial. Clin. Ther., 2005, 27(8), 1164-1180.

[20] Bansal, D., Badhan, Y., Gudala, K., et al.: Ruboxistaurin for the treatment of diabetic peripheral neuropathy: a systematic review of randomized clinical trials. Diabetes Metab. J., 2013, 37(5), 375-384.

[21] Du, X. L., Edelstein, D., Rossetti, L., et al.: Hyperglycemia-induced mitochondrial superoxide overproduction activates the hexosamine pathway and induces plasminogen activator inhibitor- 1 expression by increasing Spl glycosylation. Proc. Natl. Acad. Sci. U.S.A., 2000, 97(22), 12222-12226.

[22] Marshall, S., Bacote, V., Traxinger, R. R.: Discovery of a metabolic pathway mediating glucose-induced desensitization of the glucose transport system. Role of hexosamine biosynthesis in the induction of insulin resistance. J. Biol. Chem., 1991, 266(8), $4706-4712$
[23] Cowell, R. M., Russell, J. W.: Nitrosative injury and antioxidant therapy in the management of diabetic neuropathy. J. Investig. Med., 2004, 52(1), 33-44.

[24] Shakher, J., Stevens, M. J.: Update on the management of diabetic polyneuropathies. Diabetes Metab. Syndr. Obes., 2011, 4, 289305.

[25] Rani, V., Deep, G., Singh, R. K., et al.: Oxidative stress and metabolic disorders: Pathogenesis and therapeutic strategies. Life Sci., 2016, 148, 183-193

[26] Ballak, D. B., Stienstra, R., Tack, C. J., et al.: IL-1 family members in the pathogenesis and treatment of metabolic disease: Focus on adipose tissue inflammation and insulin resistance. Cytokine, 2015, 75(2), 280-290.

[27] Yerra, V. G., Negi, G.. Sharma, S. S., et al.: Potential therapeutic effects of the simultaneous targeting of the Nrf2 and NF- $\kappa$ B pathways in diabetic neuropathy. Redox Biol., 2013, 1(1), 394397.

[28] Cameron, N. E., Cotter, M. A.: Pro-inflammatory mechanisms in diabetic neuropathy: focus on the nuclear factor kappa $B$ pathway. Curr. Drug Targets, 2008, 9(1), 60-67.

[29] Kumar, A., Negi, G., Sharma, S. S.: JSH-23 targets nuclear factor-kappa $B$ and reverses various deficits in experimental diabetic neuropathy: effect on neuroinflammation and antioxidant defence. Diabetes Obes. Metab., 2011, 13(8), 750-758.

[30] Golbidi, S., Ebadi, S. A., Laher, I.: Antioxidants in the treatment of diabetes. Curr. Diabetes Rev., 2011, 7(2), 106-125.

[31] Zhang, W. J., Bird, K. E., McMillen, T. S., et al.: Dietary a-lipoic acid supplementation inhibits atherosclerotic lesion development in apolipoprotein E-deficient and apolipoprotein E/low-density lipoprotein receptor-deficient mice. Circulation, 2008, 117(3), 421-428.

[32] Korshunov, S. S., Skulachev, V. P., Starkov, A. A.: High protonic potential actuates a mechanism of production of reactive oxygen species in mitochondria. FEBS Lett., 1997, 416(1), 15-18.

[33] Pacher, P., Szabo, C.: Role of poly(ADP-ribose) polymerase-1 activation in the pathogenesis of diabetic complications: endothelial dysfunction, as a common underlying theme. Antioxid. Redox Signal., 2005, 7(11-12), 1568-1580.

[34] Gibson, T. M., Cotter, M. A., Cameron, N. E.: Effects of poly(ADP-ribose) polymerase inhibition on dysfunction of nonadrenergic non-cholinergic neurotransmission in gastric fundus in diabetic rats. Nitric Oxide, 2006, 15(4), 344-350.

[35] Han, T., Bai, J., Liu, W., et al.: A systematic review and metaanalysis of $\alpha$-lipoic acid in the treatment of diabetic peripheral neuropathy. Eur. J. Endocrinol., 2012, 167(4), 465-471.

[36] Guo, L., Chen, Z., Amarnath, V., et al.: Identification of novel bioactive aldehyde-modified phosphatidylethanolamines formed by lipid peroxidation. Free Radical Biol. Med., 2012, 53(6), 1226-1238.

[37] Baynes, J. W.: Role of oxidative stress in development of complications in diabetes. Diabetes, 1991, 40(4), 405-412.

[38] Huijberts, M. S., Schaper, N. C., Schalkwijk, C. G.: Advanced glycation end products and diabetic foot disease. Diabetes Metab. Res. Rev., 2008, 24(Suppl. 1), S19-S24.

[39] Anderssohn, M., Schwedhelm, E., Lüneburg, N., et al.: Asymmetric dimethylarginine as a mediator of vascular dysfunction and a marker of cardiovascular disease and mortality: an intriguing interaction with diabetes mellitus. Diab. Vasc. Dis. Res., 2010, $7(2), 105-118$.

[40] Stojanovic, I., Djordjevic, G., Pavlovic, R., et al.: The importance of L-arginine metabolism modulation in diabetic patients with distal symmetric polyneuropathy. J. Neurol. Sci., 2013, $324(1-2), 40-44$.

[41] Calabrese, V., Cornelius, C., Leso, V., et al.: Oxidative stress, glutathione status, sirtuin and cellular stress response in type 2 diabetes. Biochim. Biophys. Acta, 2012, 1822(5), 729-736.

[42] Goth, L., Eaton, J. W.: Hereditary catalase deficiencies and in creased risk of diabetes. Lancet, 2000, 356(9244), 1820-1821. 
[43] Kowluru, R. A., Atasi, L., Ho, Y. S.: Role of mitochondrial superoxide dismutase in the development of diabetic retinopathy. Invest. Ophthalmol. Vis. Sci., 2006, 47(4), 1594-1599.

[44] Fujita, H., Fujishima, H., Chida, S., et al.: Reduction of renal superoxide dismutase in progressive diabetic nephropathy. J. Am. Soc. Nephrol., 2009, 20(6), 1303-1313.

[45] Al-Rejaie, S. S., Aleisa, A. M., Abuobashish, H. M., et al.: Naringenin neutralises oxidative stress and nerve growth factor discrepancy in experimental diabetic neuropathy. Neurol. Res., 2015, 37(10), 924-933.

[46] Cakatay, U., Telci, A., Salman, S., et al.: Oxidative protein damage in type I diabetic patients with and without complications. Endocr. Res., 2000, 26(3), 365-379.

[47] Ametov, A. S., Barinov, A., Dyck, P. J., et al.: The sensory symptoms of diabetic polyneuropathy are improved with $\alpha$-lipoic acid: the SYDNEY trial. Diabetes Care, 2003, 26(3), 770-776.
[48] Ziegler, D., Low, P. A., Litchy, W. J., et al.: Efficacy and safety of antioxidant treatment with $\alpha$-lipoic acid over 4 years in diabetic polyneuropathy: the NATHAN 1 trial. Diabetes Care, 2011, 34(9), 2054-2060.

[49] Schmid, U., Stopper, H., Heidland, A., et al.: Benfotiamine exhibits direct antioxidative capacity and prevents induction of DNA damage in vitro. Diabetes Metab. Res. Rev., 2008, 24(5), 371377.

[50] Albers, J. W., Pop-Busui, R.: Diabetic neuropathy: mechanisms, emerging treatments, and subtypes. Curr. Neurol. Neurosci. Rep., 2014, 14(8), 473.

(Sztanek Ferenc dr., Debrecen, Nagyerdei krt. 98., 4032 e-mail: sztanek@belklinika.com)

\section{XVIII. kerületben EGYNAPOS SEBÉSZET kiadó}

A közel negyed évszázada sikeresen müködő ORMOS Intézet újonnan kialakított, mintegy $300 \mathrm{~m}^{2}$-es egynapos sebészeti részlege részben vagy teljes egészében (nagyon kedvező feltételekkel) bérbe vehető, akár egy óra időtartamra is.

A rendelő ÁNTSZ engedéllyel rendelkezik. Tömegközlekedéssel és autóval is könnyen megközelíthető, ingyenes parkolási lehetőség az utcán megoldott.
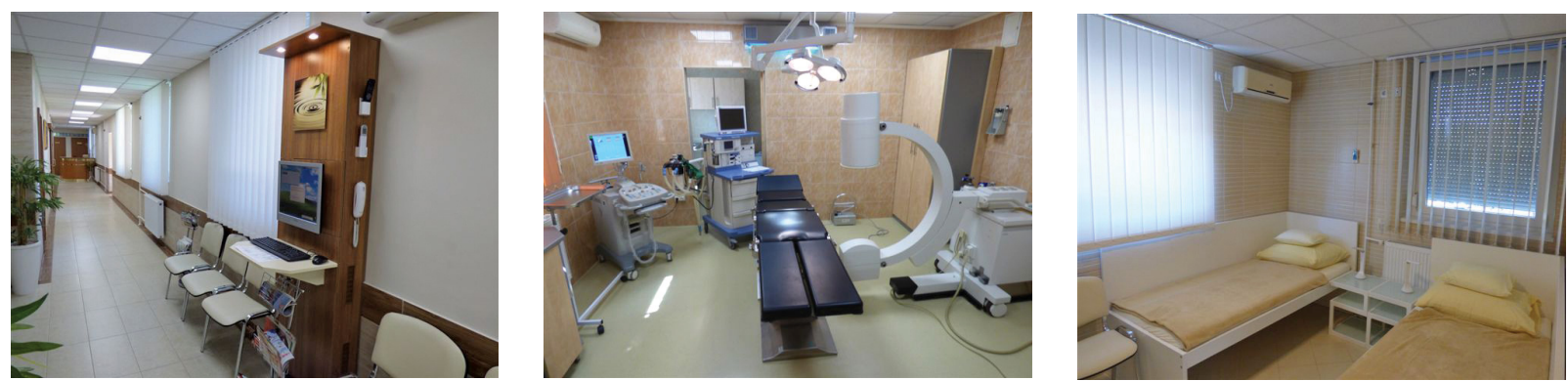

Érdeklődés esetén bővebb információért kérem, forduljon Parádi lldikó ügyvezető igazgatóhoz. Tel.: +36 205551680 